Михаило Шћепановић Филолошки факултет

Универзитет у Београду https://doi.org/10.18485/ai_vnia_bora_djordjevic.2018.1.9 821.163.41.09-1 Ђорђевић Б.

\title{
НЕСТАНДАРДНА ЛЕКСИКА У ПОЕЗИЈИ БОРЕ ЂОРЬЕВИЋА
}

У раду се анализирају типови нестандардне лексике у поезији Боре Ђорђевића. Показује се какву улогу нестандардна лексика има у остварењу поетске функције у песмама Боре Ђорђевића.

Кључне речи: улична поезија, нестандардна лексика, супстандард, табуизирана лексика, Бора Ђорђевић

Поезија Боре Ђорђевића познатија је кроз музику и његове јавне наступе него по објављеним збиркама поезије. Будући да је Ђорђевић кантаутор, све његове музичке нумере су истовремено и поетске. Иако се, како наводи Бећковић (Ђорђевић 2018, поговор), „појавио у време када у свету нико није песнике хтео ни да чита ни да слуша ако оно што су писали нису још и компоновали и певали. Тако је, држећи корак с временом, Бора Ђорђевић испредњачио" (Ђорђевић 2018:151). И управо због свог искорака у српској поезији, Бора Ђорђевић је и добитник Велике награде Иво Андрић за најбољу књигу објавтену у Републици Србији и Републиии Српској у 2017. години. Ако се само летимично погледају оцене првих збирки поезије Боре Ђорђевића: Равнодушан према плачу (1986), Хеј Словени (1988), онда се може запазити да су критичари говорили о Бориној позији као о такозваној уличној поезији односно о силаску поезије 
из тзв. уметничких висина међу народ. Тако, на пример, Александар Поповић (Ђорђевић 1986, Предговор) наводи да: „без претеривања се може рећи да поезију Боре Ђорђевића одликују сва она најдрагоценија обележја тзв. уличне поезије, а то су јасноћа, жестина, сажетост и препознатљивост”... а Петар Луковић (Ђорђевић 1988, Предговор) подвлачи да је Бора Ђорђевић „своју поезију извео испод скута 'финих уметности' и увео је у свет улице где живи и говор на ивици бријача: оштро, грубо, псовачки гнусно, али и сентиментално, с преливима депресије”...

Али то није једини разлог што је његова поезија окарактерисана овако, као улична. Она је то пре свега по употреби слободне, неспутане, уличне лексике.

Бора Ђорђевић се, наиме, у својој поезији не користи само примереним језиком него потпуно неспутаним супстандардним елементима језика, што се у првом реду види у различитим фразеологизмима, који су, иначе, карактеристика разговорног језика. Ту је и тзв. табуизирана лексика између које посебно место заузима ласцивна, безобразна лексика, унутар које не изузима чак ни најфреквентнији ласцивни глагол српскога језика, а који се у Бориној поезији тако често јавља. Није тај глагол једини мада је доминантан, него га допуњују и све расположиве лексеме српског језика које се односе на, еуфемистички речено, „оне ствари”. Тако се у поезији Боре Ђорђевића може уочити читаво семантичко поље лексема везаних за еротски чин и то не оних еуфемистички ублажених којима поезија углавном прибегава, већ оних непосредних, свакодневних, којима обичан човек прибегава у „подобним” ситуацијама.

Та лексика покаткад тражи сагласност и друге неласцивне лексике у свом, за поезију, неприродном облику. Друкчије речено, ова поезија није карактеристична само по овом типу (ласцивне, вулгарне) лексике него и 
по неграматичким облицима књижевне лексике која се прилагођава разговорном језику свакодневног човека, ослобођеног обавеза за контролисаном употребом књижевног језика у ситуацијама које су му пре хаотичне него хармоничне.

Треба, на пример, видети песму о Дражи, о коме, у времену када о њему пева Бора Ђорђевић „културни” Срби ћуте док прости народ не може да оћути неправду, а за исказивање таквог емотивног набоја неопходни су песнику глаголи ненормативно употребљени, али таква употреба је парадигматски случај. То значи да се јавља, по правилу, у песмама у којима се наглашава тачка гледишта улице односно народа, што потврђује скоро цела песма Амстердам, на коју ћемо се касније и осврнути.

Било би више него занимљиво испитати контексте, и то песничке контексте, у којима доминира стандардна, а у којима нестандардна лексика. Наш увид у песме првих збирки овог песника показује да се ласцивна лексика по правилу употребљава у финалним позицијама стихова, и то римована да би се преко риме посебно назначио њен значај у структури песме, и то, како у формалној, тако и у семантичкој, значењској структури. То Бећковић примећује и наводи „својим дугима самородним римама одужио се свом дару и оној која га је родила, мајци Неранџи, професору српског и руског језика. Само она зна колико је њен јединац заиста био груб и робустан, а колико је нама био потребан као јунак без мане”.

Слободније употребљена лексика најчешће долази у позицијама које су доминантне, чворишне тачке Бориних песама: „Можеш да се курчиш Тачи/ С туђом војском јеси јачи/ Ал јеби га мој Хашиме,/ Окупатор не плаши ме... (Пусто острво: 99).

С друге стране јасно је да је такве лексике чак много више у Бориним песмама за читање него за певање. Другим речима, Борине реминисценције односно његове 
„мисаоне строфе” најчешће су остварене у форми дистиха или пак у форми тристриха у астрофичним песмама. Она је, по правилу, „зачињена” том слободном лексиком на чијем значењу Ђорђевић и прави мисаоне досетке, по правилу везане за „немисаоне”: нпр. Од колевке па до гроба ништа не вреди пишљива боба..., Зато што чешће користи пишић јер је пишић диско мишић (Диско мишић $\left.{ }^{1}\right)$. Или пример: Док се бавим оружаном силом ти се крешеш с неким иивилом (Ко те љуби док сам ја на стражи). Нормално, у овој поезији еротска подлога песме не почива на експлицираној ласцивној лексици него и на њеним еуфемистичким, умивеним супституентима. Ту пре свега спадају дијалекатски и лексички ликови као и обиље жаргонске лексике, облици који и иначе не оскудевају у ласцивности (У клоњу сам ищао да бих тамо пишао... У приниипу морам на време да шорам,/ Мокрио сам пола сата/ и скинуо беду с врата... Пусто острво 90-91).

На који начин, на пример, песник помера тачку гледишта илустративан је показатељ употребе супстандарда, нарочито у песми Амстердам.

Неко ми је украло бицикло

Јер га нисам добро везо ланцом

На бицикло овде сам навикло

Да се не би осећало странцом

Кучићи по улицама каку

Ципелу сам умаз'о гованцом

Хоће да ме гризају у мраку

Да се не би осећало странцом

1 Примери из песама преузимани и са сајта: www.tekstovi-pesama. com 
У кафану пушу марихуану

Или неку дрогу пију с ногу

Те сам ноћи спавало под шанком

Да се не би осећало странцом

Овде вопште нема Холандези

Све Арапи, црнци и Кинези

Ту људови вопште не спавају

Само вичу и зајебавају

Ту кураве у излози седу

Ћуту, пушу, пролазнике гледу

Седу голе или у неглиже

Муштерије да им приђу ближе

Моју малу тражим по каналу

Где се водом шетају са бродом

Цео дан сам пливало за чамцом

Да се не би осећало странцом

Свуда гужва, фрка и кркљанац

Немаш појма ко је овде странац

Постало сам један Амстердамац

Да се не би осећало странац

Супстандард је овде, као што видимо заправо у хумористичкој улози зато што представља својеврсно мешање кодова. Друкчије, слободније речено, црта гастарбајтерску употребу матерњег језика. У таквој употреби долази до низа аграматичких лексема од којих се поједине подударају са дијалекатским, (нпр. 'оће, вез'о, умаз'о, би и сл.), а поједине са жаргонским (каку, зајебавају, фрка, кркљанац...) али то нису језичке доминанте ове песме. Доминанте су, без сумње, супстандардни морфолошки облици лексема. У првом реду именица у појединим падежима, 
а посебно именице са завршетком на -аи, иза којих у инструменталу једнине у нормативном језику нужно долази наставак -ем, а код песника обавезно -ом: ланцом, страниом, гованиом, чамиом. Завршно -ом није само одлика говорног језика већине старијих штокавских говора већ и својеврсно песниково пародирање говора гастарбајтера. То се још боље огледа у ненормираним личним облицима глагола, пре свега презентских облика глагола: каку, гризају, седу, гледу, пушу. Употреба датих облика глагола и именица није одлика свих старијих српских говорних типова нити пак доследно проведена одлика било ког супстандарда или жаргонског говора. Бори Ђорђевићу, песнику, дати су облици потребни не само да би осликао језичко губљење идентитета српског гастарбајтера и потпуно неприхватање новог идентитета, него да би осликао на песнички начин, а преко језичких карактеристика, посебност стања у којима се ти људи налазе. Друкчије речено, то су људи који су још увек везани језиком за матицу али потпуно неинтегрисани у нову језичку и друштвену стварност. Ђорђевић не показује то само морфолошким облицима него и губљењем осећања за исправне падежне облике. Тако се, на пример, уз егзистенцијални глагол имати у негацији који захтева генитив, употребљава номинатив: Нема Холандези..., или уз глагол седети употребљен је уместо локатива множине с предлогом $y$ - номинатив множине с истим предлогом Ту кураве у излози седу. Губљење језичког, људског идентитета, овај песник је највише подцртавао употребом глаголског придева радног у средњем роду уместо у мушком роду. Средњи род је као што је познато „нерод”, јер се не може одредити по полу, чиме се заправо живо биће (човек), пребачен у средњи род, представља као предмет, као „нелице”. Тако ће кроз читаву песму Ђорђевић употребљавати глаголске облике који се творе са глаголским придевом радним, најчешће 
потенцијал у средњем, уместо у мушком роду (да се не би осећало страниом) при чему није никако случајно што је потенцијал ту у контактном положају с именицом странаи, јер је дато подвођење (у средњи род) „страно” човеку као бићу, човеку као човеку.

Није ово једини глагол. Где год може, песник уместо мушког употребљава средњи род, ради подцртавања људског идентитета човека изгубљеног у иностранству (на бицикло овде сам навикло... иео дан сам пливало за чамиом... постало сам један Амстердамац... те сам ноћи спавало под шанком).

И све је ово још и „зачињено” последњом строфом датом на енглеском језику, тако да пред читаоцем израња потпуна интерференција (на нивоу песме) исквареног матерњег и несавладаног страног енглеског језика.

Разлози уптребе нестандардне лексике нису везани само за смисаону, значењску структуру песме, него и за њену формалну структуру. Наиме, песма је састављена од 7 катрена на српском јеику и завршне октаве на енглеском језику. Сви катренски стихови строго су римовани, па су поједини облици о којима је говорено употребљени и ради реализације риме као нпр. Овде вопште нема Холандези, све Арапи, ирнии и Кинези... А да је, којим случајем, песник употребио нормативни облик Холандеза, та употреба би довела до изневеравања риме (према Кинезима). И на крају, што је веома интересантно, Ђорђевић употребљава неологизам, дакле скоро сопствени песнички облик неприсутан у књижевном језику, у дијалекту понегде у рубним говорима у траговима, а ни у супстандарду језика српског, а то је прилог вопште. Разлог није тешко докучити јер је употреба иницијалног в понекад диференцијална црта Срба према штокавцима несрбима, као у примерима ваистину, васпоставити и сл. Тако да стављање гастарбајтерском говорнику прилог вопште уместо уопште песник га, на неки начин, том 
једном једином лексемом и етнички идентификује.

Често се песник сам поистовећује са гастарбајтерском судбином зато што је сва песма испевана у доживљеној ја форми, типа: ми је, нисам, сам, да ме, моју малу, тражим и сл. Дакле, и после овог аналитичког увида у само један Ђорђевићев наслов, да се закључити да је излазак из књижевног језика и прелазак на дијалекатски жаргонски израз у песничким књигама Боре Ђорђевића последица жеље да се песнички глас повеже са сегментима културе и то језичким облицима у којима је она сачувана. Потреба нашег песника почива и на чињеници да „скрајне” повремено и лично искуство и да проговори о ономе што чини важан аспект у судбинама људи на ширем српском говорном простору и да, за казивање о томе употреби оне језичке облике у којима је то искуство првобитно настајало. На овај начин се сигурније ослањамо на уверење да лотмановски речено „култура подразумева чување претходног искуства", а песнички глас Боре Ђорђевића је недвосмислено глас који је био Богом дан да опева те, насловом одређене песме, омеђене, културне обрасце.

\section{Извори и литература}

Вуковић 2000: Novo Vuković, Putevi stilističke ideje, Jasen, Podgorica - Nikšić

Драгићевић 2018: Рајна Драгићевић, Српска тексика у прошлоти и данас, МС, Нови Сад

Ђорђевић 2018: Бора Ђорђевић, Пусто острво, Андрићев институт, Андрићград

Ковачевић 2000: Милош Ковачевић, Стилистика и граматика стилских фигура, Кантакузин, Крагујевац

Речник 1985: Rečnik književnih termina, Nolit, Beograd, 1985. 
Михаило Шчепанович

\section{НЕСТАНДАРТНАЯ ЛЕКСИКА В ПОЭЗИИ БОРЫ ДЖОРДЖЕВИЧА}

В работе дается обзор нестандартной лексики в поэзии Боры Джорджевича и анализируются субстандартные элементы языка данной поэзии в диапазоне от диалектизмов до фразеологизмов. Указывается каким образом данный голос поэта связан с сегментами культуры и на каких языковых формах он базируется.

Ключевые слова: уличная поэзия, нестандартная лексика, субстандарт, табуизированная лексика, Бора Джорджевич 